\title{
IMPORTANCE OF NON-ECONOMIC FACTORS FOR ECONOMICS
}

\section{LETUNIC, S. \& DRAGICEVIC, M.}

Abstract: Important economists who have pointed out existence of economic and noneconomic factors are already A.Marshall than G.Myrdall and A.Sen. The analysis of the social situation and system is grateful (such analysis is mainly used in economic growth theory). Institutional factors have a greater role in developing countries. Economic freedom is relatively objective measure of institutional differences between countries in order to investigate their effect on trade in consumer goods and services. National, international economic and social development is in interdependence with democracy and human rights. Specialized agencies of the OUN act according to the criteria of application of Human Rights. Based on the methods of synthesis and desk research, in addition to the analysis of economic and non-economic factors, the need for interdisciplinary and multidisciplinary approach to economic problems can be concluded.

Key words: economic factors, non-economic factors, institutional factors, human rights, interdisciplinary approach
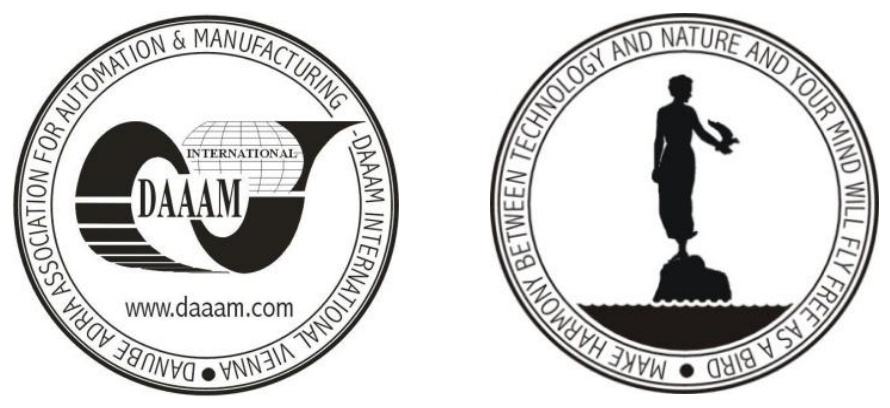

Authors' data: Dr. Sc. Letunic S[tijepo] ; Dr. Sc. Dragicevic M[arija] , University of Dubrovnik, Department of Economics and Business Economics. Lapadska obala 7, 20000 Dubrovnik, Croatia, stijepo.letunic@du.t-com.hr, marija.dragicevic@ounidu.hr

This Publication has to be referred as: Letunic, S[tijepo] \& Dragicevic, M[arija] (2014). Importance of Non-Economic Factors for Economics, Chapter 11 in DAAAM International Scientific Book 2014, pp.145-152, B. Katalinic (Ed.), Published by DAAAM International, ISBN 978-3-901509-98-8, ISSN 1726-9687, Vienna, Austria

DOI: 10.2507/daaam.scibook.2014.11 


\section{Introduction}

On the basis of research results, using the methods of synthesis and desk research, the aim of this paper is to point out the importance of non-economic factors in economics. In accordance with the objectives set out in this paper, a hypothesis is that in addition to economic non-economic factors play an increasing role in economics. Already D.Hume puts human practical experience in the center of his deliberations, its relativity and limitations, introduces the psychological, cultural and historical factors that form man and his environment (Hume, 2004). Social construct has strong repercussions on the economy. Social organization of individual countries (Tekic et al, 2012) limits their economic development and social pathology is present in many countries. Modern economics statistical methodology is still not perfect, of course, but in the last 20-30 years it has improved to the extent unthinkable for then economists. What among economists was previously considered true in 1960s is because of this empirical methodology no longer considered true. However, in many of the principles of economics presence of dogmatic thinking in economics remains strong (Sharma, 2010). Yet compared to the utilitarian model of classics - in the economic science there has been a shift towards irrational psychology (what opposes neoliberal theory). The importance of neoclassical theory is reduced due to the human psychology and the belief that the behavior of individuals within the market is rational (Weil, 1989). In classic economic crisis comes to irrational behavior in the market interaction.

\section{Economic and non-economic factors}

Important economists who have pointed out the existence of economic and noneconomic factors and should be noted are Nobel prize winners G.Myrdall and A.Sen, also before them A.Marshall (Hodgson, 2005). Considering the correlation between the presence of democracy and human rights with economic development Z.Bazdan quotes A.Sen in the sense that economic growth and social development go together with less poverty and more democracy (Bazdan, 2008). After receiving the Nobel Prize in 1998s, A.Sen said that "there is no national and international economic and social development and international peace and security - without democracy and human rights" (Bazdan, 2008). In summary there should be highlighted some of the major non-economic factors with a significant impact on economic growth and social development and which are used in the economical science research. These are: culture, religion (so, for example, observed countries can be catholic or protestant), the role of family, class, tradition, the role of the individual, social and political dependence, the role of government and the existence of economic duality in individual countries (Afghah \& Morteza, 1998). Most literature on institutions and economic welfare relates to the growth literature, for example, X, X., Sala-i-Martin,

"I Just Ran Two Million Regressions." (Sala-i-Martin ,1997). Same author uses economic growth and real GDP per capita as the dependent variable. Institutional variables to be considered include religion (Barro, Cleary, 2003), language as a resource of human capital (Lee, 2012), corruption (Mo, 2001), war (Blomberg \& 
Hess, 2006), etc. Further are factors that belong to the social pathology (e.g., war, corruption, crime). Some other variables also used in modern economic empirical research are democracy, rule of law, the state share of spending in the economy, legal structures, colonial ties countries, the Index of Economic Freedom. The general consensus is somewhat intuitive: countries with less autocratic rule, be it government or religious, less corruption, and less disruption have better economic performance (Sonora, 2014). R.Sonora (2014) points out that economic freedom represents a relatively objective measure of institutional differences across countries in order to investigate their impacts on trade in consumer goods and services. The same author uses sub-indices of freedom used by the Fraser Institute's Economic Freedom of the World freedom to evaluate the disaggregated impacts of changes in freedom. The overall Fraser Institute's Economic Freedom of the World Index (EFWI) is an amalgam of five separate freedom "Area" indices, which are the sub indices of the overall Fraser Institute's index, including: size of government, legal structure and security of property rights, access to sound money, freedom to trade internationally, regulation of credit, labor, and business (Sonora, 2014). Depken and Sonora, for example, used the overall index freedom to determinants: the impact on trade flows, and to analyze its asymmetric impact on exports, imports and total trade volume (Depken \& Sonora, 2005). The conclusion pointed out by Sobel and Coyne is that it is impossible to determine which of the many state institutions is responsible for economic prosperity (Sobel \& Coyne, 2011). The state is facing a host of problems in the political decisioning, which can not adequately be met without cooperation with other countries and supranational factors (Cakardic, 2006). Institutional factors, such as legal structures and military influence play a bigger role in the developing countries. The role of institutions in the international economy is well known. The word "institution" takes many sundry forms, from informal cultural norms and subjective measures of values to more well-defined tangible legal and/or government organizations and easily identifiable entities such as religion or historic relationships (Sonora, 2014). The analysis of the social situation and planning, especially in developing countries and countries in the third and fourth world, is grateful considering the backwardness of many countries in this respect (such analysis is mostly used in economic growth theory). Social construct of some oil exporting countries limits their economic development (social pathology in many of petroleum exporting countries). Economic performance and success under British colonial legal system has contributed to higher growth in the later post-colonial countries, compared for example with French or not-British colonies. Thus, for example, bureaucracy in India is different from one in the Congo. China also had advantage of British colonial force (Acemoglu et al, 2000). Additional revenues do not contribute to the development of individual countries in equal measure (Wade, 2004). In some, such as Nigeria, Venezuela (oil exporting countries), it does not influence the increase of their own standard. Dutch disease presents empirical cases found in individual countries and for the reason that the structure of domestic production may change due to debt or technological shock (movement of production possibilities curve away from the original one), what ultimately leads to a change in the share of internationally tradable and non-tradable goods. (Babic, M. \& Babic, A., 2008). 
Many poor countries that depend on a few natural resource commodity exports have had poor economic performance. The structure of their economy and the low skill endowment of the population make them dependent on trade of these goods (Wade, 2004). Especially in less developed countries, institutional, social and legal barriers (which result in the impossibility of borrowing countries in the global financial markets) can seriously affect economic outcome, what may lead to the potential pitfalls of poverty and imbalances (Edwards, 2007). This means non-economic factors need to be pondered more in modern economics. Trade and financial assets in their own way make countries dependent (such as in a group of Latin American countries), what explains dependency theory (Kay \& Gwynne, 2000).

\section{Influence of economic and non-economic factors on productivity of work, technology and FDI}

Economists who differ widely over short-run priorities, such as inflation tradeoffs or welfare reform, are in strong agreement about the importance of productivity growth over longer periods (Burinskiene, 2012). Technological change was responsible for up to three quarters of all growth (Landau et al, 1996). Total income $\mathrm{Y}$ is an economic function (production function with Solow technical progress) $\mathrm{Yt}=$ F (K, L At), (Babic, 2007), where A is the so-called Solow residual and is linked to productivity and it is significantly lower in less developed economies. Residual A we can also present itself as the "brain" and it is not evident only in the form of finished products (eg. computer), but represents a vector of economic and non-economic factors. In the economics present are continuous attempts to discover what is in this "black box" and the most significant is intellectual capital, ie. human factor represented through term intellectual capital (Druzic, 2004). Labour productivity is a key factor for long-term competitiveness in domestic and international competitive environment (Uzik \& Vokorokosova, 2007). But for example, economies of France and Germany are known to be very similar (for example regarding data that refers to university educated, the number of industrial plants per person, space: land - coastal areas, agricultural land), and the question is why Germany is more successful (http://stats.oecd.org/, accessed 2014-03-25). The reason may lie in politicians aversion towards risk preferences, demonstrations of workers or students, what suggests that institutional factor in these countries is different (Nitu at al, 2012). The constellation of states and groups of states in the international economy largely depends on the dispersion of technology and technological innovation. Knowledge, research and development bring the highest added value and are the biggest factors of development and success in the international market. Linder's theory of comparative advantage argues that foreign trade is more dependent on consumer tastes from different countries, than the difference in production costs, what empirically means that majority of trade in industrial products takes place between the economically most developed countries (Babic, M., \& Babic, A., 2008). For most countries, foreign sources of technology account for ninety percent or more of the growth of productivity (Druzic \& Jovancevic, 2003). The interaction of foreign direct investment (FDI) with human capital in developing countries significantly affects 
positive effect of growth, whereas in countries with technological gap it has a significant negative impact. The significance of FDI therefore seems to depend on the particular case of individual country, depending on the economic, institutional and technological conditions of the country receptors ( $\mathrm{Li} \& \mathrm{Liu}, 2005)$. In the endogenous growth model foreign direct investment (FDI) affects an increase in domestic growth through the generation of technological diffusion from developed countries to the host country. Technology cannot always be easily and immediately transferred. For example World Bank (WB) borrows money to Ghana (or one of the most countries of sub-Saharan Africa or another country of the fourth world) but the results of research relating to the construction sector reveal significant difficulties in the transfer of technology and knowledge (T \& C) in industrial sub-sectors and between foreign and domestic enterprises (Osabutey et al, 2013). In education and technological development stabilized habits (second nature) regulate the behavior and interaction of the participants (Dosi et al, 2000). Input for the development of these habits is different in some societies, what leads to institutional diversity in relation to habits of thought (Hodgson, 1988). Therefore, technological and innovation systems are likely to vary. Especially in the high technology, some national innovation systems and technological trajectories are different, due to differences in conditions and initiatives (Bartholomew, 1997). These habits result in an inert historical presence (Dosi et al, 2000).

\section{Crucial subject of human rights}

In conclusion, according to Z.Bazdan, in contemporary international economy and politics there is no more important topics than human rights and the specialized agencies of the UN, such as the International Monetary Fund (IMF), the World Bank Group (WB Group), World Trade Organization (WTO), as well as other UN agencies, do act on the criteria of application of the Universal Declaration of Human Rights of 1948. In all programmatic acts of these seventeen specialized agency of the UN, the base is the 30th article of the Universal Declaration of Human Rights. Due to the large impact on all environments of socio-political life in the international community, this declaration has become a global human rights instrument and has grown into the common law, which has not happened to any document in the history (Bazdan, 2008). On the basis of that great document (on the level of declaration), two international pacts go one step further. Specifically, they deal with some other additional rights. For the first time in the history of the UN these pacts have established mechanism by which certain organs of the UN have the right "to interfere in the internal affairs" of a country member of the UN (Bazdan, 2008). In this sense, according to L.Veljak, regarding theoretical and practical questions about the possibilities of emancipation of globalization processes of their neoliberal framework and limitations (also dogmatism based on neoclassical economics), (Veljak, 2010), assumptions and modalities of alter-globalization should be considered, what means globalization of solidarity, globalization of justice (of course, not in terms of a more powerful), the globalization of human rights (which must have primacy over all rights produced by of human beings alienated, from them independent entities), and finally 
globalization of responsibility (Veljak, 2009). This is possible to achieve through productive cooperation of philosophy and interdisciplinary and multidisciplinary critical approach to economic problems which relate to complex issues of globalization (Veljak, 2010). That, also for the future research, raises the question if all decisioning can be left to economists in the measure it is now (Koslowski, 2001).

\section{Conclusion}

Despite huge advances in empirical methodology, in many of the principles of economics presence of dogmatic thinking in economics remains strong. Yet compared to the utilitarian model of classics - in the economic science there has been a shift towards irrational psychology. Some of the major non-economic factors with a significant impact on economic growth and social development are: culture, religion, the role of family, class, tradition, role of the individual, social and political dependence, the role of government, religion, language as a resource of human capital, corruption, factors that belong to the social pathology. Some other variables also used in modern economic empirical research are democracy, rule of law, the state share of spending in the economy, legal structures, colonial ties countries, index of economic freedom. Examples of countries rich in primary resources show that additional revenues do not contribute to the development of individual countries in equal measure. In education and technological development stabilized habits (second nature) regulate the behavior and interaction of the participants. These habits result in an inert historical presence. Regarding crucial subject of human rights in all programmatic acts of specialized agencies of the UN the base is the 30th article of the Universal Declaration of Human Rights. Globalization of solidarity, globalization of justice, the globalization of human rights and globalization of responsibility is possible to achieve through productive cooperation of philosophy and interdisciplinary and multidisciplinary critical approach to economic problems which relate to complex issues of globalization. This means non-economic factors need to be pondered more in modern economics and it raises the question if all decisioning can be left to economists in the measure it is now.

\section{References}

Acemoglu, D., Johnson S., Robinson, A., J.(2000). The Colonial Origins of Comparative Development: An Empirical Investigation, NBER Working Paper No. 7771, National Bureau of Economic Research, Cambridge, SAD, ISSN 1073-2489

Afghah, S. \& Morteza, (1998). Economic and non-economic factors in Economic Development: the concepts and their differences, available from http://www.pishgam.org/economics/Thesis/Chapt3.pdf , Accessed 2014-04-02 Babic, M. \& Babic, A. (2008). International economy, Sigma savjetovanja, ISBN 978-953-55053-0-3, Zagreb

Babic, M.(2007). Macroeconomics, Mate, ISBN 978-953-246-041-4, Zagreb

Barro, R., Cleary, R., (2003). Religion and economic growth across countries, American Sociological review, Vol.68, 760-781 , ISSN 1939-8271 
Bartholomew, S.(1997). National systems of Biotechnology Innovation: Complex Interdependence in the Global System, Journal of International Business Studies, Vol.28, ISSN 0047-2506

Bazdan, Z.(2008). Democracy and Human Rights- Heart of International Economy and Politics, University of Dubrovnik, ISBN 978-953-7153-17-5, Dubrovnik

Blomberg, S. B., Hess, G.D.(2006), How Does Violence Tax Trade?, Review of Economics and Statistics, Vol. 88, 599-612, ISSN 88-4-599

Burinskiene, A. (2012). The Theoretical Link Between Trade and Productivity, Proceedings of the 23rd International DAAAM Symposium, Katalinic, B.(Ed), 287304 , ISBN 978-3-901509-91-9, Vienna, (11)2012, Published by DAAAM International, Vienna

Cakardic, A.(2006). Global Neo-liberal Democracy in the "Minimal" State, "Reduction of Politics", Filozofska istrazivanja (Philosophical research), Vol. 26, No. 4, ISSN 1848-2309

Depken, C. A. \& Sonora, R. J. (2005). Asymmetric Effects of Economic Freedom on International Trade Flows, International Journal of Business and Economics, Vol. 4, 141-155, ISSN 1465-7287

Dosi, G., Nelson, R.R. \& Winter, S.G.(2000). The Nature and Dynamics of Organizational Capabilities, Oxford University Press, Oxford, ISSN 1467-8284

Druzic, I., \& Jovancevic, R.(2003). Croatian economic development, Politicka kultura, ISBN 9789536213511, Zagreb

Druzic, I., (2004). Resources and Markets of the Croatian Economy, Politicka kultura, ISBN 953-6213-73-7, Zagreb

Edwards, T., H.(2007). Returns to Education and the Mankiw-Romer-Weil result, Economic Bulletin, Vol.15, No.24, ISSN 1545-2921

Hodgson , G.(2005). Alfred Marshall versus the historical school?, Journal of Economic Studies, Vol. 32, No. 4, 331-348, ISSN 01443580510618563

Hodgson, G.(1988). Economics of Institutions: A Manifesto for a Modern Institutional Economics, Polity Press, ISBN 9780745602776 , Cambridge

Hume, D.(2004). Political Discourses, Politicka kultura, ISBN 953-6213-80-X, Zagreb

Kay, C. \& Gwynne, R.(2000). Relevance of Structuralist and Dependency Theories in the Neoliberal Period: A Latin American Perspective, Journal of developing societes, Vol.16, No.1, ISSN 0169-796X

Koslowski, P.(2001). Warum die Philosophie die Ökonomie nicht nur den Ökonomen überlassen kann, Wirtschaft - Wo ist die Philosophie?,( Why the philosophy of the economy not only may allow economists, economy - Where's the philosophy?) Koslowski P.(Ed), 1-16, Physica-Verlag, ISBN 3-7908138-93, Heidelberg

Landau, R.,Taylor, T. \& Wright, G. (1996.). The Mosaic of economic growth, Stanford University Press, ISBN 0-804-72604-3, California

Lee, C. G.(2012). English Language and Economic Growth: Cross-Country Empirical Evidence, Journal of Economic and Social Studies, Vol. 2, 5-20, ISSN $1986-8502$

Li, X., \& Liu, X.(2005). Foreign Direct Investment and Economic Growth: An Increasingly Endogenous Relationship, World Development, Vol. 33, No. 3, ISSN 0305-750X 
Malik, T., H.(2013). National institutional differences and cross-border universityindustry knowledge transfer, Research Policy, Vol. 42, No. 3, ISSN 0048-7333

McCleary, R. M.(2008). Religion and Economic Development: A Two-way Causation, Policy Review, Vol. 148, ISSN 1519761

Mo, P. H. (2001). Corruption and Economic Growth, Journal of Comparative Economics, Vol. 29, 66-79, ISSN 0147-5967

Nitu A., Renata D. \& Feder, E. (2012). The Impact of Small and Medium-Sized Firms' Entrepreneurial Behaviour on Labour Market Dynamics in Central and Eastern Europe, Proceedings of the 23rd International DAAAM Symposium, Katalinic, B.(Ed), 215-220, ISBN 978-3-901509-91-9, Vienna, (11)2012, Published by DAAAM International, Vienna

Osabutey, E., Williams, K. \& Debrah, J.(2013). The potential for technology and knowledge transfers between foreign and local firms: A study of the construction industry in Ghana, Journal of World Business, ISSN 1090-9516

Podobnik, B., J., Shao, D., Njavro, D, Ivanov, P., C. \& Stanley, H. E. (2008). Influence of Corruption on Economic Growth Rate and Foreign Investment, European Physical Journal B, Vol. 63, 547-550, ISSN 2000-1703

Sala-I-Martin, X. X.(1997). I Just Ran Two Million Regressions, American Economic Review, Vol. 87, 178-183, ISSN 0002-8282

Sharma, S. (2010). Reflections on the Philosophical Foundations of Economics, Mikrorad, ISBN 978-953-6286-94-2, Zagreb

Sobel, R. S. \& C. J. Coyne(2011). Cointegrating Institutions: The Time-Series Properties of Country Institutional Measures, Journal of Law and Economics, Vol. 54, ISSN 65304

Sonora, R., J.(2014). All Economic Model is not created equal: Evidence from a Gravity Model, Contemporary Economic Policy, Vol. 32, No. 1, ISSN 1465-7287

Tekic, Z., Cosic, I. \& Katalinic, B.(2012). The missing link-Knowledge creation and inovation, Proceedings of the 23rd International DAAAM Symposium, Katalinic, B.(Ed), 229-232, ISBN 978-3-901509-91-9, Vienna, (11)2012, Published by DAAAM International, Vienna

Uzík, M. \& Vokorokosova, R. (2007). Labour Productivity as a factor of Competitiveness-a Comparative Study, Narodohogospadarski obzor, Vol. 3, ISSN 1213-2446

Veljak, L. (2009). Inexorability of Globalization, necessity of an alternative and the question of responsibility, Filozofska istraživanja, (Philosophical research) Vol. 29, no. 113, ISSN 1848-2309

Veljak, L.(2010). Contributions to the critique of false alternatives, Otkrovenje, ISBN 9788683353651 , Beograd

Wade, R., H.(2004). Is Globalization Reducing Poverty and Inequality?, World Development, Vol. 32, No. 4, 567-589, ISSN 0305-750X

Weil, P.(1989). Why is the risk-free rate so low if agents are so averse to Intertemporal Substitution?, The equity premium puzzle and the risk-free rate puzzle, Journal of Monetary Economics, Vol. 24, No. 3, 01/1989, 401-421, ISSN 0304-3932 http://stats.oecd.org/, OECD.Stat , accessed 25.03.2014 